
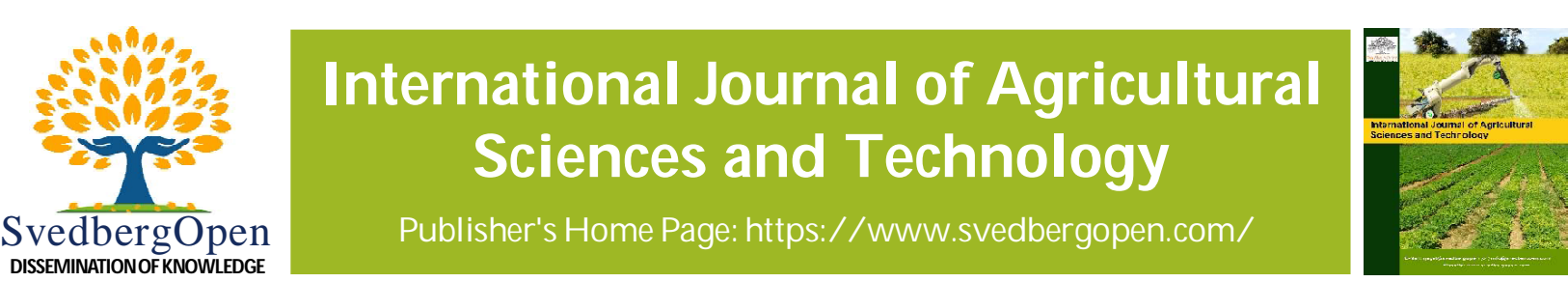

\title{
Determination of minerals, vitamin content and antioxidant activity of cucumber and watermelon fruits from South-Western part of Nigeria
}

\author{
Modupe A. Omoniyi ${ }^{*}$ and Aduradara M. Alli ${ }^{2}$ \\ ${ }^{1}$ Department of Chemistry, University of Lagos, Lagos, Nigeria. E-mail: omoniyimodupe @ gmail.com \\ ${ }^{2}$ Department of Chemistry, University of Ibadan, Ibadan, Nigeria. E-mail: macomoniyi02@ gmail.com
}

Article Info

Volume 1, Issue 1, February 2021

Received : 14 November 2020

Accepted : 12 January 2021

Published : 05 February 2021

doi: 10.51483/IJAGST.1.1.2021.15-23

\begin{abstract}
Fruits are indispensable in today's world owing their tremendous health benefits. Cucumber and watermelon are commonly consumed fruits worldwide. In this study, antioxidant potential of crude methanol extract of different concentrations of cucumber and watermelon were screened for antioxidant activity using total phenolic content, ferric reducing power (FRAP), ferric thiocyanate (FTC) tests and free radical scavenging (DPPH) assay. They are good source of calcium, magnesium and copper with appreciable amounts of vitamin $\mathrm{C}$ $(143.360 \pm 101.400 \mathrm{mg} / 100 \mathrm{~g})$ for cucumber and vitamin A $(90.980 \pm 22.860 \mathrm{mg} / 100 \mathrm{~g}$; $29.475 \pm 0.575 \mathrm{mg} / 100 \mathrm{~g}$ ) for both watermelon and cucumber respectively. It was found that polyphenolics compounds were maximum in watermelon $(87.04 \pm 0.55 \mathrm{mg} / \mathrm{g} \mathrm{GAE}$ in concentration $100 \mathrm{mg} / \mathrm{mL}$ ). The extracts showed a potent DPPH free radical scavenging activity; cucumber had maximum percentage inhibition at $20 \mu \mathrm{g} / \mathrm{mL}$ concentration $(29.2 \%)$ compared to watermelon at $40 \mu \mathrm{g} / \mathrm{mL}$ concentration $(13.5 \%)$. These fruits also exhibited fairly good antioxidant activity with in both FRAP $(0.517 \mathrm{mg} / 100 \mathrm{~g} ; 0.317 \mathrm{mg} / 100 \mathrm{~g})$ and FTC $(17.2 \% ; 31 \%)$ methods for watermelon and cucumber respectively.

Keywords: Cucumber, Watermelon, Antioxidants activities

(C) 2021 International Journal of Agricultural Sciences and Technology. This is an open access article under the CC BY license (https://creativecommons.org/licenses/by/4.0/), which permits unrestricted

use, distribution, and reproduction in any medium, provided you give appropriate credit to the original author(s) and the source, provide a link to the Creative Commons license, and indicate if changes were made.
\end{abstract}

\section{Introduction}

Reactive Oxygen Species (ROS) are chemically reactive chemical specie containing oxygen such as peroxides, superoxide, hydroxyl, alpha-oxygen and singlet oxygen. Thus, we are encountered daily by this reactive species that are extremely destructive for the health of living bodies and oxidative stress are in bound when exposed to such reactive species. In living bodies, neutralization of this reactive species occurs through their reaction with complex systems of antioxidant processes mediated by endogenous antioxidant enzymes. These enzymes may be insufficient for permanent oxidative stress. Hence, presence of bioactive compounds that are therapeutic within plants origin have proven to balance the rate of ROS to stop the ominous effects in living bodies.

Antioxidants are substances which delay or inhibit oxidative damages. Antioxidants either inhibit the formation of free alkyl radicals at the initiation step or interrupt the propagation of free radical chain reaction. Most commercial antioxidants in use are monohydroxy or polyhydroxy phenolic compounds with various ring substitutions. They require

\footnotetext{
* Corresponding author: Modupe A. Omoniyi, Department of Chemistry, University of Lagos, Lagos, Nigeria.

E-mail: omoniyimodupe@gmail.com
} 
low activation energy to be able to donate hydrogen or antioxidant free radical ring to the lipid free radical to form stable compounds (Decker and Terwilliger, 2000).

The initiation and progression of certain diseases such as diabetes, cancer, cardiovascular disease, inflammatory diseases are as a result of oxidative stress, a condition characterized by excessive generation of ROS beyond the capacity of the natural antioxidant defense system of the body. Certain fruits contain various antioxidants including vitamin $\mathrm{C}$, vitamin $\mathrm{A}$, vitamin $\mathrm{E}$, polyphenols, flavonoids which have been reported to provide protection against some of these diseases (Moon and Shibamoto, 2009).

These antioxidants can act as free radical scavengers, decompose peroxide, quench singlet and triplet oxygen as well as inhibit some enzymes that may enhance oxidation. By decreasing the high levels of free radicals generated by metabolism, antioxidants decrease oxidative stress, carcinogenesis and prevent biochemical and physiological injury that can lead to functional impairment or cell death. Because of the richness in valuable nutrients and potential health benefits, fruits are readily consumed on a daily basis. In this line, in our laboratory, we have been interested to the study of antioxidants effects of plants origin, especially those which are widely distributed in Nigeria. Particular attention is given to fruits consumed daily by most people (Nagarajaiah and Prakash, 2011).

\section{Materials and methods}

\subsection{Collection of fruit sample}

The fruits: Cucmber (Cucumis sativus) and watermelon (Citrullus lanatus) were purchased from Kuto market in Ogun state, Nigeria. Fruits samples were stored at ambient temperature $\left(26 \pm 2^{\circ} \mathrm{C}\right)$ prior until used. Fruit samples' identity was also labeled at the Laboratory for identification.

\subsection{Sample preparation}

Upon arrival, the fruit were washed and rinsed with distilled water to remove any apparent dirt after which they were dried in the in an oven (Memmert Inc. Germany) at $40^{\circ} \mathrm{C}$. Air drying was carried out using horizontal air flow over samples that was placed in a single layer of aluminum trays so as to reduce the water of crystallization. The fruit samples were then pulverized into some air-tight containers at $4{ }^{\circ} \mathrm{C}$ for antioxidant screenings.

\subsection{Determination of mineral content}

Analysis for Calcium, Potassium, Copper, Magnesium, Selenium and Manganese were carried out after wet digestion using the method of AOAC (2000). Ground samples $(0.5 \mathrm{~g})$ of each fruit was boiled $\left(100{ }^{\circ} \mathrm{C}\right)$ with $5 \mathrm{~mL}$ concentrated nitric acid $\left(\mathrm{HNO}_{3}\right)$ and $5 \mathrm{~mL}$ of $30 \%$ hydrogen peroxide $\left(\mathrm{H}_{2} \mathrm{O}_{2}\right)$ solution continuously for about two hours in an electric heating mantle (HP220, LITEC Product Inc. Albany, N-Y., USA) until clear solutions were obtained. These were cooled, filtered through Whatman no 45 filter papers and then through $<0.45$ Millipore filter papers. Filtrates were made up to the $25 \mathrm{~mL}$ mark of the volumetric flasks with distilled water and then used to analyze for the individual minerals using Atomic Absorption Spectrophotometer (Buck Scientific AAS Model 210, equipped with single slot burner and air acetylene flame).

\subsection{Determination of vitamin A ( $\beta$-carotene) content}

Analysis of vitamin A was determined based on method described by the Association of Analytical Chemist (AOAC, 1990) method. $10 \mathrm{~g}$ of each samples extracted were weighted into $250 \mathrm{~mL}$ boiling flask. $95 \%$ ethanol with about four times volume weight of the sample was added into the boiling flask. Then, $10.0-20.0 \mathrm{~mL}$ of $20 \%$ potassium hydroxide (KOH) and few boiling chips were added. This was refluxed at a rate of about two drops per second with controlled temperature. Samples were heated by refluxing for $30 \mathrm{~min}$ and then cooled at room temperature.

The hydrolysate was extracted three times with $50 \mathrm{~mL}$ of hexane and then water was added until solution was neutral to phenolphthalein. The extract was filter washed through anhydrous Sodium sulphate. Volume of extract was reduced by using rotary evaporator. Then mobile phase was added to the mark up point. Sample was filtered through $0.45 \mu$ membrane filter. The supernatant underwent analyses by using High Performance Liquid Chromatography (HPLC). The HPLC condition was summarized as follow an aliquot of $2 \mathrm{~mL}$ of concentrated extracts were evaporated under running Nitrogen, re-dissolved in $2 \mathrm{~mL}$ acetone, passed through $0.45 \mu \mathrm{m}$ Millipore membrane and $20 \mu \mathrm{L}$ aliquot were injected into the HPLC system. The methanol, ethyl acetate and acetonitrile (88:10:2 v/v/v) was used as mobile phase at flow rate 1.3 $\mathrm{mL} / \mathrm{min}$ and detection was carried out at the wavelength of $450 \mathrm{~nm}$. 


\subsection{Determination of vitamin C (Ascorbic Acid) content}

Analysis of vitamin C was determined based on method described by the Association of Analytical Chemist (AOAC, 1990) method with slight modifications. $10 \mathrm{~g}$ of grinded sample was weighted in $250 \mathrm{~mL}$ conical flask. Then, metaphosphoric acid-acetic acid solution was added and makeup to volume of $200 \mathrm{~mL}$. The solution was homogenized by using magnetic stirrer and filtered in $250 \mathrm{~mL}$ conical flask with a funnel and filter paper. $10.0 \mathrm{~mL}$ of sample was removed and filled in 100 $\mathrm{mL}$ of conical flask. Two replicates were prepared of each samples and was determined using titration of filtrate until pink color was formed in the solution.

\subsection{Determination of vitamin E content}

Analysis of vitamin E was determined based on method described by Association of Analytical Chemist (AOAC, 1990) method with slight modifications. $10 \mathrm{~g}$ of each samples were weighted into $250 \mathrm{~mL}$ conical flask respectively by using analytical balance (Sartorius, Germany). $50 \mathrm{~mL}$ of the absolute Ethanol was added followed by $50 \mathrm{~mL}$ of Potassium hydroxide and $0.25 \mathrm{~g}$ of ascorbic acid. Then the conical flask was heated for $30 \mathrm{~min}$ at $40{ }^{\circ} \mathrm{C}$ by refluxing process. The solution was cooled at room temperature and transferred into separating funnel. $25.0 \mathrm{~mL}$ of petroleum ether was added and vigorously shake. After two separation layer was formed, upper solution (petroleum ether extract) was collected and lower solution was removed in a beaker throw waste pipe. The lower solution was added into separating funnel and $25 \mathrm{~mL}$ of ether was added two times to repeat the extraction step. Ether extracts was combined and washed with water to neutralize it becomes phenolphthalein. Then, the ether extract was filtered through anhydrous Sodium sulphate and evaporated to dryness under $\mathrm{N}_{2} .10 .0 \mathrm{~mL}$ of Methanol was added for dilution and the sample was filtered through $0.45 \mu$ membrane filter. The supernatant was under went analyses by using High Performance Liquid Chromatography. The chromatographic condition used were as follow: An Ultra sphere octadecylsily (ODS) Hypersil (C18; $5 \mu \mathrm{m}$, reversed-phase column, 4.6 x $150 \mathrm{~mm}$ ). Methanol and deionised water (95:5) at pH 2.2 was used as mobile phase with a flow rate of $1.0 \mathrm{ml} / \mathrm{min}$ and detection was carried out at $238 \mathrm{~nm}$.

\subsection{Determination of total phenol content (TPC) in fruit sample}

Total phenol content was determined using Folin-ciocalteau method (Roesler et al., 2006). Folin-ciocalteau method allows the estimation of all flavonoids, anthocyanins, and nonflavonoid phenolic compounds, including phenols and tannins, (that is, all phenolic present in the sample) (Roesler et al., 2006). The total phenol content of the various fruits was determined by mixing $0.5 \mathrm{~mL}$ aliquot of freshly prepared sample extract with equal volume of water, $0.5 \mathrm{~mL}$ FolinCiocalteu's reagent, and $2.5 \mathrm{~mL}$ of saturated solution of sodium carbonate $\left(\mathrm{Na}_{2} \mathrm{CO}_{3}\right)$. The absorbance was measured after $40 \mathrm{~min}$ at $725 \mathrm{~nm}$ (Singleton et al., 1999). Garlic acid was used at concentrations of $0.0 \mu \mathrm{g} / \mathrm{mL}, 3.0 \mu \mathrm{g} / \mathrm{mL}, 6.0 \mu \mathrm{g} / \mathrm{mL}$, $12.0 \mu \mathrm{g} / \mathrm{mL}, 18.0 \mu \mathrm{g} / \mathrm{mL}, 24.0 \mu \mathrm{g} / \mathrm{mL}$ and $30.0 \mu \mathrm{g} / \mathrm{mL}$ to prepare total phenol standard curve. Total phenol content was extrapolated from the standard curve using the absorbance values and expressed as garlic acid equivalents (g/ $100 \mathrm{~g} \mathrm{GAE})$.

\subsection{Determination of free radical scavenging ability (DPPH)}

Free radical scavenging activity of the fruits extracts was determined using the radical 1, 1- diphenyl-2-Picrylhydrazyl (DPPH), which is widely used to evaluate the free radical scavenging activity of natural antioxidants (Brand-Willams et al., 1995; Bondet et al., 1997; Sanchez- Moreno et al., 1998). A $1000 \mu \mathrm{L}$ volume of the fruit supernatant was mixed with $1000 \mu \mathrm{L}$ of $0.4 \mathrm{M} \mathrm{DPPH} \mathrm{radical}$ in ethanol solvent $(0.004 \% \mathrm{~W} / \mathrm{V})$. The mixture was left in the dark for 30 min before reading the absorbance at $517 \mathrm{~nm}$. Radical scavenging was expressed as the inhibition percentage and was calculated using the formula of Yen and Chen (1995);

$$
\% \text { Inhibition }=\frac{\left(\mathrm{ABS}_{\mathrm{DPPH}}-\mathrm{ABS}_{\text {EXTRACT }}\right)}{\mathrm{ABS}_{\mathrm{DPPH}}} \times 100
$$

where: $\quad \mathrm{ABS}_{\mathrm{DPPH}}=$ absorbance of DPPH radical at $517 \mathrm{~nm}$ and

$\mathrm{ABS}_{\text {EXTRACT }}=$ absorbance of extract of fruits at $517 \mathrm{~nm}$.

\subsection{Determination of ferric reducing antioxidant power (FRAP)}

Reducing power of the crude extracts of fruits was determined according to the method of Yen and Chen (1995). The crude extracts $(5 \mathrm{~mL})$ of fruit or butylated hydroxytoluene $(5 \mathrm{~mL})$ were separately mixed with equal volume of $0.2 \mathrm{M}$ phosphate buffer $(\mathrm{pH}, 6.6)$ and $1 \%$ Potassium ferricyanide. The mixture was incubated at $50{ }^{\circ} \mathrm{C}$ for $20 \mathrm{~min}$, after which an equal volume of $1 \%$ Trichloro acetic acid (TCA) was added to the mixture and then centrifuged at $3000 \mathrm{~g}$ for $10 \mathrm{~min}$. The 
upper layer (the supernatant) of the suspension was mixed with distilled water and $0.1 \% \mathrm{FeCl}_{3}$ in the ratio of $1: 1: 2$, and the absorbance measured at $700 \mathrm{~nm}$. Increased absorbance of the reaction mixture indicated increased reducing power.

\subsection{Determination of antioxidant activity of crude extracts of fruits by the Ferric Thiocyanate (FTC) method}

The Ferric Thiocyanate (FTC) method was adopted from Osawa and Namiki (1981) method. The fruit crude extracts (2.5 $\mathrm{mL}$ ) were added to $2.5 \mathrm{~mL}$ of $95 \%(\mathrm{~V} / \mathrm{V})$ ethanol, and then mixed with $4.1 \mathrm{ml}$ of linoleic acid $(2.51 \% \mathrm{~V} / \mathrm{V})$ in $99.5 \%(\mathrm{~V} / \mathrm{V})$ ethanol, $8 \mathrm{~mL}$ of $0.05 \mathrm{M}$ phosphate buffer ( $\mathrm{pH} 7.0), 3.9 \mathrm{~mL}$ of distilled water and then kept in the dark in screw-capped containers at $4{ }^{\circ} \mathrm{C}$. To $0.1 \mathrm{ml}$ of this solution was added $9.7 \mathrm{~mL}$ of $75 \%(\mathrm{~V} / \mathrm{V})$ ethanol and $0.1 \mathrm{~mL}$ of $30 \%(\mathrm{~W} / \mathrm{V})$ ammonium thiocyanate. A $0.1 \mathrm{~mL}$ volume of $20 \mathrm{mM}$ Ferrous chloride in $3.5 \%$ (V/V) hydrochloric acid was added to the reaction mixture, and the absorbance of the resulting red solution measured after $3 \mathrm{~min}$ at $500 \mathrm{~nm}$ repeatedly at interval of $24 \mathrm{~h}$ until the control (no extract) reached the maximum value. This was run in duplicates and results averaged. The percentage inhibition of linoleic acid peroxidation was calculated as:

$$
\left.\% \text { Inhibition }=100-\frac{\left\{\mathrm{ABS}_{\mathrm{SAMPLE}}\right.}{\mathrm{ABS}_{\text {BLANK }}} \times 100\right\}
$$

\section{Statistical analysis}

All data obtained were subjected to statistical analysis using Statistical Package for Social Sciences (SPSS), results are expressed as means \pm S.D. Significant different was set at $p<0.05$ and also line graphs were also used to illustrate their concentrations.

\section{Results and discussion}

\subsection{DPPH radical scavenging activity of fruits}

Table 4 shows the results of DPPH free radical scavenging activities of five fruits at five different concentrations $(20 \mu \mathrm{g} /$ $\mathrm{mL}-100 \mu \mathrm{g} / \mathrm{mL})$.

Table 1: Mineral composition (mg / $100 \mathrm{~g})$ of fruits

\begin{tabular}{|l|c|c|c|c|c|c}
\hline Fruits & Calcium & Potassium & Copper & Manganese & Selenium & Magnesium \\
\hline Cucumber & $208.97 \pm 0.14$ & $100.82 \pm 0.35$ & $0.23 \pm 0.02^{\mathrm{b}}$ & $0.09 \pm 0.01^{\mathrm{b}}$ & $2.55 \pm 0.01^{\mathrm{d}}$ & $8.33 \pm 0.01$ \\
\hline Watermelon & $222.55 \pm 0.38$ & $133.76 \pm 0.35$ & $0.18 \pm 0.01^{\mathrm{ab}}$ & $0.08 \pm 0.00^{\mathrm{b}}$ & $2.52 \pm 0.04^{\mathrm{d}}$ & $8.47 \pm 0.02$ \\
\hline
\end{tabular}

Note: * Values represent Mean \pm Standard Error of Mean (SEM). The mean values in the same column with different superscripts letter are significantly different $(p<0.05)$.

Table 2: Vitamin content of fruits

\begin{tabular}{|l|c|c|c|}
\hline Fruits & Vitamin A $(\mathbf{m g} / \mathbf{1 0 0} \mathbf{g})$ & Vitamin C $(\mathbf{m g} / \mathbf{1 0 0} \mathbf{g})$ & Vitamin E $(\mathbf{m g} / \mathbf{1 0 0} \mathbf{g})$ \\
\hline Cucumber & $29.475 \pm 0.515$ & $143.360 \pm 101.450$ & $0.075 \pm 0.015$ \\
\hline Watermelon & $90.980 \pm 22.860$ & $72.895 \pm 36.515$ & $2.000 \pm 2.00$ \\
\hline \multicolumn{2}{|l}{ Note: * Values represent Mean \pm Standard Error of Mean (SEM). } \\
\hline
\end{tabular}

Table 3: Total phenolic content

\begin{tabular}{|l|c|}
\hline Fruits & Total Phenol (mg/100 g GAE) \\
\hline Cucumber & $26.93 \pm 0.55^{\mathrm{a}}$ \\
\hline Watermelon & $87.04 \pm 0.55^{\mathrm{b}}$ \\
\hline
\end{tabular}

Note: * Values represent Mean \pm Standard Error of Mean (SEM). The mean values in the same column with different superscripts letter are significantly different $(p<0.05)$. 


\subsection{Mineral composition}

The results of the mineral elements and vitamin compositions of the samples are shown in Tables 1 and 2 respectively. Watermelon showed greater concentration of minerals tested for in the samples — calcium, potassium, magnesiumthan cucumber with greater concentrations in trace elements. The concentration of calcium and potassium for watermelon $(222.5 \pm 0.38 \mathrm{mg} / 100 \mathrm{~g} ; 133.76 \pm 0.35 \mathrm{mg} / 100 \mathrm{~g})$ and for cucumber $(208.97 \pm 0.14 \mathrm{mg} / 100 \mathrm{~g} ; 100.82 \pm 0.35 \mathrm{mg} / 100 \mathrm{~g})$ is of particular significance $(p<0.05)$ when compared to the presence of other minerals in the samples. The calcium content obtained in this study for watermelon $(222.00 \mathrm{mg} / 100 \mathrm{~g})$ was extremely higher when compared to values obtained by Ekpete and Edori (2013) for watermelon $(7.00 \mathrm{mg} / 100 \mathrm{~g})$. However, it was relatively similar to value reported by Omer (2015) for watermelon $(183.30 \mathrm{mg} / 100 \mathrm{~g})$. Values of cucumber $(75.56 \mathrm{mg} / 100 \mathrm{~g})$ obtained by Abbey et al. (2017) was relatively lower when compared to result obtained in this study for cucumber $(208.97 \mathrm{mg} / 100 \mathrm{~g})$. Calcium plays a vital role in the development and sustenance of strong bones and teeth (especially in fetuses, infants, children and the elderly), regulation of muscular contraction and relaxation, regulation of nerve function and absorption of cyanocobalamin (vitamin $\mathrm{B}_{12}$ ) (Otitoju et al., 2014). Calcium may therefore be useful in the prevention of osteoporosis in the elderly (Dias,

\begin{tabular}{|l|c|c|c|c|c|}
\hline \multicolumn{6}{|l|}{ Table 4: Percentage inhibition of free radical scavenging of fruits } \\
\hline Fruits & $\mathbf{2 0} \boldsymbol{\mu \mathrm { g } / \mathbf { m L }}$ & $\mathbf{4 0} \boldsymbol{\mu \mathrm { g } / \mathbf { m L }}$ & $\mathbf{6 0} \boldsymbol{\mu \mathrm { g } / \mathbf { M l }}$ & $\mathbf{8 0} \boldsymbol{\mu \mathbf { g } / \mathbf { m L }}$ & $\mathbf{1 0 0} \boldsymbol{\mu \mathbf { g } / \mathbf { m L }}$ \\
\hline Cucumber & 29.2 & 25.7 & 23.1 & 19.2 & 17.3 \\
\hline Watermelon & 2.8 & 13.5 & 5 & 5 & 9.4 \\
\hline
\end{tabular}

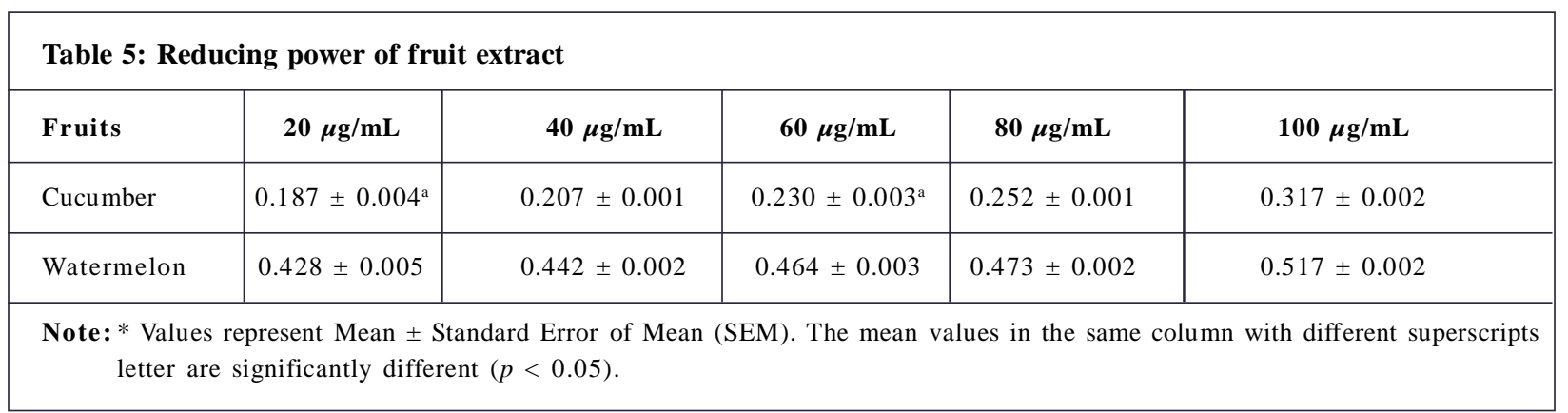

\begin{tabular}{|c|c|c|c|c|c|}
\hline Fruits & $20 \mu \mathrm{g} / \mathrm{mL}$ & $40 \mu \mathrm{g} / \mathrm{mL}$ & $60 \mu \mathrm{g} / \mathrm{mL}$ & $80 \mu \mathrm{g} / \mathrm{mL}$ & $100 \mu \mathrm{g} / \mathrm{mL}$ \\
\hline Cucumber & $36.31 \pm 0.42 b^{c}$ & $44.35 \pm 0.42^{\mathrm{a}}$ & $55.21 \pm 0.21$ & $62.80 \pm 0.42^{\mathrm{a}}$ & $66.22 \pm 0.21^{\mathrm{a}}$ \\
\hline Watermelon & $41.22 \pm 1.47^{\mathrm{d}}$ & $53.69 \pm 0.17^{\mathrm{d}}$ & $59.23 \pm 0.42$ & $66.37 \pm 0.42^{\mathrm{b}}$ & $82.15 \pm 0.42^{c}$ \\
\hline \multicolumn{6}{|c|}{$\begin{array}{l}\text { Note: * Values represent Mean } \pm \text { Standard Error of Mean }(\mathrm{SEM}) \text {. The mean values in the same column with different superscripts } \\
\text { letter are significantly different }(p<0.05) .\end{array}$} \\
\hline
\end{tabular}

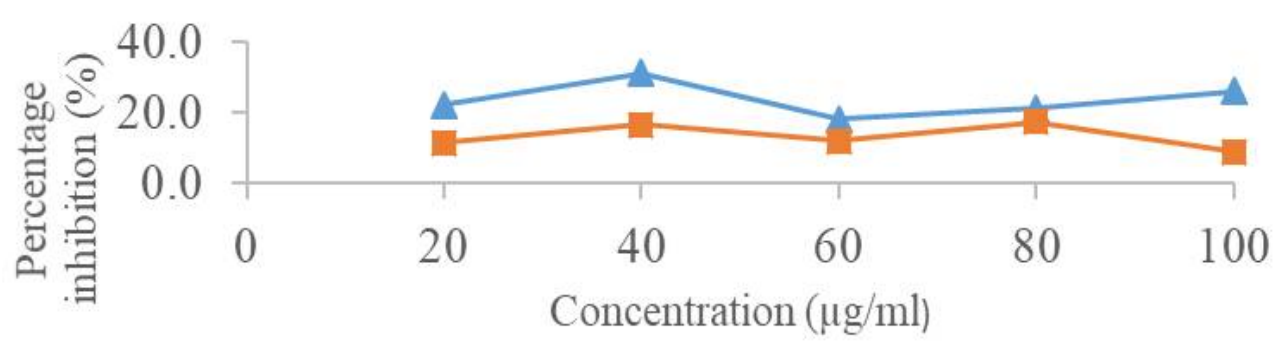


2012). Potassium content for watermelon obtained in this study $(133.76 \mathrm{mg} / 100 \mathrm{~g})$ was relatively similar to value obtained by Ekpete and Edori (2013) for watermelon $(125.00 \mathrm{mg} / 100 \mathrm{~g}$ ) but lower when compared to result reported by Omer (2015) for watermelon $(11.19 \mathrm{mg} / 100 \mathrm{~g})$. Potassium is the major cations in intracellular fluid and function in the maintenance of weight (Igile et al., 2013), regulation of acid-base balance, conduction of nerve impulse, muscular contraction (especially of the cardiac muscle), correct functioning of the cell membrane, regulation of the sodium-potassium adenosine triphosphate (ATPase) system and the maintenance of fluid volume (Agbaire, 2011). The ranges of concentration of magnesium $(8.33 \pm 0.01 \mathrm{mg} / 100 \mathrm{~g}-8.47 \pm 0.02 \mathrm{mg} / 100 \mathrm{~g})$ obtained in this study. Result generated in this study for watermelon $(8.47 \mathrm{mg} / 100 \mathrm{~g})$ which was lower when compared to work reported by Ihesinachi and Eresiya (2014) for watermelon $(30.21 \mathrm{mg} / 100 \mathrm{~g})$. Magnesium is needed for normal functioning of the body. It activates the enzymes necessary for carbohydrate metabolism (FAO, 2001).

Selenium is, however, a micro mineral has its own content to be approximately $(2.5 \mathrm{mg} / 100 \mathrm{~g})$ in both cucumber and watermelon. Selenium is needed in a very small amount in the body but must be supplied regularly from the diet. Selenium though toxic if taken in excess exceeding the Tolerable Upper intake mineral of 400 mircogram per day can lead to selenosis (FAO, 2001). The result of copper content ranged from $0.18 \mathrm{mg} / 100 \mathrm{~g}$ to $0.23 \mathrm{mg} / 100 \mathrm{~g}$. This range of values were similar to result obtained by Wall (2006). Values obtained in this study for cucumber $(0.23 \mathrm{mg} / 100 \mathrm{~g})$ was higher when compared to result reported by Abbey et al. (2017) for cucumber $(0.11 \mathrm{mg} / 100 \mathrm{~g})$ however, values were similar for watermelon obtained by Ekpete and Edori (2013) for watermelon $(0.18 \mathrm{mg} / 100 \mathrm{~g})$.

\subsection{Vitamin content}

Vitamin C (Ascorbic acid) is a water soluble vitamin which also has antioxidant properties. The vitamin $\mathrm{C}$ content of the samples ranged from $72.90 \pm 36.52 \mathrm{mg} / 100 \mathrm{~g}-143.36 \pm 101.45 \mathrm{mg} / 100 \mathrm{~g}$. The difference in amount of vitamin C absorbed in each of the fruit type could be attributed to temperatures the fruits were exposed to. It was observed that fruits exposed to higher temperature absorbed the least of the ascorbic acid and vice-versa. This is as a result of increase in temperature (Dioha et al., 2011). The vitamin C content reported by Ugbogu and Ogodo (2015) for watermelon was lower when compared to the value obtained in this study for watermelon $(72.90 \mathrm{mg} / 100 \mathrm{~g}$ ) and Offor et al. (2015) for watermelon. The significantly $(p<0.05)$ higher vitamin A content of watermelon could be attributed to higher beta-carotene content. Just like vitamin $\mathrm{C}$, vitamin $\mathrm{E}$ is key antioxidant nutrient. It is a fat-soluble vitamin that plays vital role in our defense mechanism against free radical damage. Vitamin E content ranged from $0.020 \pm 0.020(\mathrm{mg} / 100 \mathrm{~g})$ to $2.00 \pm 2.00(\mathrm{mg} / 100 \mathrm{~g})$. The vitamin E content in this study for watermelon $(2.00 \mathrm{mg} / 100 \mathrm{~g})$ was higher when compared to the work of Ugbogu and Ogodo (2015) for watermelon $(0.34 \pm 0.03 \mathrm{mg} / 100 \mathrm{~g})$. The deviation of this results from those reported by some other researchers of the fruit samples analyzed may be as a result of some of the other factors that affects minerals and vitamin content in fruit. These factors include degree of ripeness, climate and also the amount of fertilizer used during cultivation. Light and temperature have been reported to affect chemical composition of crop (Klein and Perr, 1982).

\subsection{Determination of Total Phenolic Content (TPC)}

In this present study, methanol extract of watermelon contains highest TPC $(p<0.05)$ compared to cucumber. Watermelon have reported to contain lower phenolic content obtained in this study. These include Ellong et al. (2015) and Choudhary et al. (2015). Total phenol content for cucumber in this study compares favorably with the ethanol extract of peel and whole obtained by Yunusa et al. (2018). However, in contrast with the ethanol and water extracts of flesh and seed. Furthermore, the variation may be due to the presence of lipophilic compounds which contribute to the highest phenolic content. Toxicity is considered for the solvent to be used for extraction of phytochemicals. Ethanol and water are the most commonly used solvent (Yoswathana and Eshtiaghi, 2013). The folin-cocalteau calometric method used for phenolic determination was based on single electron transfer in which phenolic compounds are oxidized at high $\mathrm{pH}$ yielding a colored product at wavelength of $725 \mathrm{~nm}$ after $40 \mathrm{~min}$. It has been shown that other reducing agents such as vitamin $\mathrm{C}$ can interfere in the analysis. Nevertheless, it is thought that vitamin $\mathrm{C}$ does not interfere in the analysis of orange only due to its similarity to the high temperature used for total phenolic extraction. Minimum and maximum data obtained may be due to experimental and environmental conditions.

\subsection{Antioxidant Assays (DPPH)}

Recently, antioxidants have attracted considerable attraction in relation to radicals and oxidative stress. Thus, antioxidants inhibit oxidative reaction of lipids in food system by formation of a complex between the antioxidant radicals and lipid radicals. The DPPH free radical scavenging at different concentrations showed that all fruits were significantly $(p<0.05)$ different with least percentage inhibition (4.4\%) in watermelon at the highest concentration. At $20 \mu \mathrm{g} / \mathrm{mL}$ and $40 \mu \mathrm{g} / \mathrm{mL}$, cucumber showed a double percentage inhibition as compared to watermelon. The variation in the free radical scavenging 
activities can be attributed to environmental factors such as climate, soil and light exposure as reported by Ikram et al. (2009). Radical scavenging ability of fruits extracts showed a potential decrease with increase in the concentration of fruits extracts. Therefore, it is necessary to follow the daily nutrient intake of fruits as prescribed by FAO. The fruits extracts were able to reduce the stable free radical of DPPH to the yellow colored diphenyl pircylhydrazone. This simply shows that both cucumber and watermelon contain some active constituents that are capable of donating hydrogen to free radical in other to remove electrons (odd) responsible for its reaction. DPPH radical scavenging method results are not affected by substrate polarity

\subsection{Reducing Power (FRAP) method}

The FRAP method measures the antioxidant capacity of a given substance with a reference. This method is based on the reduction of ferric tripyridyltriazine to its ferrous colored form in the presence of antioxidants. The method measures the reductive power of antioxidants and it is calculated by the transformation of $\mathrm{Fe}$ (III) to $\mathrm{Fe}$ (II) in the presence of fruit extracts. From Table 4, reducing power increases with an increased fruits extracts. Therefore, the result shows that all samples increased their reducing ability when concentration of extracts was increased. High absorbance in fruit extracts indicates a high antioxidants concentration. Absorbance increases with concentration of fruits extracts resulting to an increase in reducing power. Therefore, the result shows that all samples increased their reducing ability. This result was similar to the result reported by Emynur Shafekh et al. (2012) for Vigna sinensis and Sharma and Adarsh (2013) for Parkinsonia aculeate L. leaves. Watermelon had the highest antioxidants while cucumber at $20 \mu \mathrm{g} / \mathrm{mL}$ had the lowest antioxidants. However, this result of antioxidants value were different with DPPH where the highest antioxidants was cucumber at $20 \mu \mathrm{g} / \mathrm{mL}$ followed by $40 \mu \mathrm{g} / \mathrm{mL}$ while watermelon had the least antioxidants at $100 \mu \mathrm{g} / \mathrm{mL}(4.4 \%)$. Emynur Shafekh et al. (2012) reported that methanol has the highest ability to reduce Fe(III). The reduction of Fe(III) may be attributed to the hydrogen donation from phenolic compounds. The results exhibit significant $(p<0.05)$ reducing power as it possesses various mechanisms such as prevention of side chains, initiation, decomposition of peroxides, reducing capacity and radical scavenging.

\subsection{Ferric Thiocyanate (FTC) method}

Antioxidant activity of crude extracts is measured using FTC method. Yunusa et al. (2018) recommended the use of different assay for determination and comparison of the antioxidant capacity in food or plant origins. This method measures the amount of peroxide produced during the initial stages of lipid oxidation, in which peroxide reacts with ferrous chloride and form ferric ions. The ferric ions then combine with ammonium thiocyanate to produce ferric thiocyanate of red coloration. A darker coloration results to a high absorbance (Huda-Faujan et al., 2009). From the FTC method, it was found that the antioxidants activities increased with increasing concentration of fruits extracts. Cucumber crude extract showed the lowest absorbance at the first concentration $(20 \mu \mathrm{g} / \mathrm{mL})$. Absorbance of each samples increases progressively by concentration. Lower absorbance values indicate higher antioxidant activities. Antioxidant activities are higher during the initial of the experiment than end of the experiment. At $100 \mu \mathrm{g} / \mathrm{mL}$ concentration all samples showed absorbance values than initial concentration $(20 \mu \mathrm{g} / \mathrm{mL})$. At $60 \mu \mathrm{g} / \mathrm{mL}$, both crude extracts were significantly $(p<0.05)$ different with values for cucumber (55.21) and watermelon (59.23). Higher absorbance values showed lower antioxidant activities. Increase in concentration causes antioxidants to reduce and this might be due to exposure to lights. Substance with antioxidant effect can easily be damaged with light when exposed. Therefore, it is necessary to ensure all procedure are being carried out in a dark area. From the graph, the higher percentage of inhibition, the higher antioxidants activity and also with a lower percentage of inhibition, a lower antioxidant activity will be produced. The percentage of inhibition increases from $20 \mu \mathrm{g} / \mathrm{mL}$ to $40 \mu \mathrm{g} / \mathrm{mL}$ concentrations and the subsequent measurements are in a scattered pattern with some higher and some lower. This might be probably due to handling error as incubation only proceeds up to three days. The results obtained in this study for fruit samples also compares positively with Shafekh et al., 2012 for Vigna sinensis.

\section{References}

Abbey, B.W., Nuwachoko, N. and Ikinma, G.N. (2017). Nutritional value of cucumber cultivated in three selected states of Nigeria J. Biochem. Anal Biochem. 6(3), 17-22.

Agbaire, P.O.(2011). Nutritional and Anti-nutritional Levels of Some Local Vegetables (Vernonia amygdalina, Manihot esculenta, Teiferia occidentalis, Talinum triangulare and Amaranthus spinosus) from Delta State, Nigeria. Journal of Applied Science and Environmental Management. 15(4), 625-628.

Association of Official Analytical Chemists AOAC. (1990). Official method of analysis of the Association of Official Analytical Chemists. $15^{\text {th }}$ edition. Washington, DC. 
Association of Official Analytical Chemists AOAC. (2000). Official method of analysis of the Association of Official Analytical Chemists. $16^{\text {th }}$ edition. Washington, DC

Bondet, V., Bran-Williamos, W. and Beset, C. (1997). Kinetics and mechanism of antioxidant activity, using the DPPH free radical method. Lebansm Wiss Technology 30, 609-615.

Brand-Williams, W., Carelier, M.E. and Beset. C. (1995). Use of free radical method to available antioxidant activity. Lebensm-Wiss Technology 28: 25 - 30.

Choudhary, B.R., HAldoar, S.M. and Sharma, S.K. (2015). Phytochemical and antioxidant in watermelon genotypes under hot arid region. Indian Journal of Agriculture Science. 85(3), 414-417.

Decker, H. and Terwilliger, N. (2000). COPs and Robbers: Putative evolution of copper oxygen-binding proteins. Journal of Experimental Biology. 203 (12), 1777-1782.

Dias, J.S. (2012). Nutritional quality and health benefits of vegetables: A review. Food and Nutrition Sciences, 3(10), $1354-1374$.

Dioha, I.J., Olugbami, O., Onuegbu, T.U., and Shahiu, Z. (2011). Determination of ascorbic acid content of some tropical fruits by iodometric titration. Int. J. boil. Chem 5(5), 2180-2184.

Ekpete, O.A and Edori, O.S. (2013). Proximate and mineral composition of some Nigerian fruits. International Journal of Research and Reviews in Pharmacy and Applied Science. 3(2), 287-295.

Ekpete, O.A and Edori, O.S. (2013). Proximate and Mineral Composition of Some Nigerian Fruits. International Journal of Research and Reviews in Pharmacy and Applied Science. 3(2), 287-295.

Ellong, E.N., Billard, C., Adenet, S., and Rochefort, K., (2015). Polyphenols, carotenoids vitamin C content in tropical fruit and vegetables and impact of processing method. Food and Nutrition Science. 6(3), 299-313.

Emynur Shafekh, S., Mohd Adzim, K.R., Catherine, C.C.W., Siti Syakiroh, Z.A., Ummu Habibah, A., Norhayati, A.H., Nor Farhanah, M.Y., Noor Husna, Z., Siti Nafizah, M.B., Azlina, M., Noor Shahhida Sazura, A.R. and Ahmad Zubaidi, A.L. (2012). Total phenolic content and in vitro antioxidant activity of Vigna sinensis. International Food Research Journal. 19(4), 1393-1400.

FAO (2001). Human vitamin and mineral requirements. Report of a Joint WHO/FAO Expert Consultation. Bangkok, Thailand.

Huda-Faujan, N., Noriham, A., Norrakiah, A.S. and Babji, A.S. (2009). Antioxidant activity of plants methanolic extracts containing phenolic compounds. African Journal of Biotechnology. 8(3), 484-489.

Igile, GO., Iwara, I.A., Mgbeje, B.I.A., Uboh, F.E. and Ebong, P.E. (2013). Phytochemical, proximate and nutrient composition of vernonia calvaona hook (Asterecea): A green-leafy vegetable in Nigeria. Journal of Food Research, 2(6), 401404

Ihesinachi, K. and Eresiya, D. (2014). Evaluation of heavy metals in orange, pineapple, avocado pear and pawpaw from a farm in kami, bori River Stare Nigeria. International Journal of Public and Environmental Health 4(2), 87-94.

Ikarim, K., Hainida, E., Khoo, H.E., Jalil, A.M., Ismail, A., Azlan, A., Saadiah, H., Nazri, M. and Azil, R. (2009). Antioxidant capacity and total phenolic content of Malaysian underutilized fruits. Journal of Food Composition and Analysis. 22(5), 388-396.

Klein, B.P. and Perry, A.K. (1982). Ascorbic acid and vitamin activity in selected vegetables from different geographical areas of the United States. Journal of Food Science, 47, 941-945.

Moon, J.K. and Shibamoto, T. (2009). Antioxidant assays for plant and food components. Journal of Agricultural and Food Chemistry, 5(7), 1655-1666.

Nagarajaiah, S.B. and Prakash, J. (2011). Chemical composition and antioxidant potential of peels from three varieties of banana. Asian Journal of Food and Agro-Industry, 4(1), 31-46.

Offor, C.E., Ugwu, P.C and Esther, U.A. (2015). Determination of ascorbic acid content of fruits and vegetables. International Journal of Pharmacy and Medicinal Sciences, 5(1), 10-15.

Omer, M.B. (2015). Assessment of some heavy metals in fruit from local market in Khantourism state. Sudan Academy of Science, 20(4), 201- 207.

Osawa, T. and Namiki (1981). A novel type of antioxidant isolated from leaf wax of eucalyptus leaves. Journal of Agricultural Biology and Chemistry. 45(3), 735-739. 
Otitoju, G.T.O., Nwamarah, J.U., Otitoju, O. and Iyeghe, L.U. (2014). Nutrient composition of some lesser known green leafy vegetables in Nsukka Lga of Enugu State Department of Biochemistry, Faculty of pure and Applied Sciences, Natural Science Research Unit. Journal of Biodiversity and Environmental Sciences. 4(4), 233-239.

Roesler, R., Malta, G.M., Carrasco, L.C. and Pastore, G. (2006). Evaluation of the antioxidant properties of the Brazilian cerrado fruit Annona crassiflora (Araticum). Journal of Food Science, 71 (2), C102-C107.

Sanchez-Moreno, C., Laurran, J.A. and Saura-Calixto, E.A. (1998). Procedure to measure the anti-radical efficacy of polyphenols. Journal of Agricultural and Food Chemistry. 7(6), 270 -276.

Singleton, V.L., Orthofer, R. and Lamuela- Raventos, R.M. (1990). Methods in Enzymology 299, 152-178.

Shafekh, E.S., Rohin, M.A. and Catherine. C.C.W. (2012). Total phenolic content and in-vitro antioxidant activity of Vigna sinensis. International Food Research Journal 19(4), 1393-1400.

Sonia, Sharma., and Adarsh Pal, Vig (2013). Evaluation of in-vitro antioxidant properties of methanol and aqueous extract of Parkinsonia aculeata L. leaves. The Scientific World Journal. 15(3), 23-30.

Ugbogu, O.C and Ogodo, A.C. (2015). Microbial floral, proximate composition and vitamin content of juices of three fruits bought from a local market in Nigeria. International Journal of Chemical Engineering and Application, 6(6), 440-443.

Wall, M.M. (2006). Ascorbic acid, vitamin A and mineral compostion of banana and papaya cultivars from Huwaii. Journal of Food Compostion and Analysis, 1(9), 434-445.

Yen, G.C. and Chen., H. Y. (1995). Antioxidant activity of various tea extracts in relation to their anti-mutagenicity. Journal of Agricultural and Food Chemistry, 4(6), 849-854.

Yoswsthana, N. and Eshtiaghi, M.N., (2013). Optimization of subcritical ethanol extraction for xanthone from mangosteen pericap. International Journal of Chemical Engineering and Applications. 6(2), 115-119.

Yunusa, N.N., Kura, A.U., Ladan, A.A. and Magaji, S.Y. (2018). Preliminary photochemical analysis and antidepressant activity of n-hexane fraction of Moringa oleifera ethanol leaf extract in mice. Acta Scientific pharmaceutical sciences. 10(2), 84-88.

Cite this article as: Modupe A. Omoniyi and Aduradara M. Alli (2021). Determination of minerals, vitamin content and antioxidant activity of cucumber and watermelon fruits from South-Western part of Nigeria. International Journal of Agricultural Sciences and Technology. 1(1), 15-23. doi: 10.51483/IJAGST.1.1.2021.15-23. 